\title{
To Iterate Or Not To Iterate? Using The WACC In Equity Valuation
}

Patrick J. Larkin, Fayetteville State University, USA

\begin{abstract}
The "textbook" discounted cash flow (DCF) valuation method involves estimating a target debt ratio for the firm, discounting firm cash flows at the WACC to estimate firm value, then subtracting the current value of debt to get equity value. This method gives the correct equity value in situations in which the firm will move toward the target debt ratio after the transaction is complete, such as takeovers and capital budgeting projects. The textbook method does not work well for estimating equity value in passive investments in which leverage is unlikely to change as a result of the potential transaction. Estimating equity value in passive investments when leverage is unlikely to change requires a simple iterative procedure to correct for circularity, which is demonstrated here. This situation sows confusion among students and practitioners. Finance scholars and textbook authors are aware of the situation but the author has never seen it clearly explained in prior textbooks or articles.
\end{abstract}

Keywords: Weighted Average Cost of Capital; WACC; Circularity; Equity Valuation

\section{THE TEXTBOOK METHOD}

ntroductory finance textbooks, including Brealey, Myers, and Allen (2011), recommend using the current market values of debt and equity to estimate the subject firms' target market value debt ratio, and then using that debt ratio to estimate the WACC. Next, the estimated free cash flows to the firm are discounted at the WACC to estimate firm value, and the market value of debt is subtracted to estimate the equity value. This "textbook method" of equity valuation can be described by the following four equations:

$\mathrm{V}_{\mathrm{F}}=\mathrm{FCFF}_{1} /(1+\mathrm{WACC})^{1}+\ldots+\mathrm{FCFF}_{\mathrm{N}} /(1+\mathrm{WACC})^{\mathrm{N}}+\mathrm{FCFF}_{\mathrm{N}+1} /(\mathrm{WACC}-\mathrm{G}) *(1 /(1+\mathrm{WACC}))^{\mathrm{N}}$

$\mathrm{WACC}=\mathrm{R}_{\mathrm{D}} * \mathrm{~W}_{\mathrm{D}}+\mathrm{R}_{\mathrm{E}} *\left(1-\mathrm{W}_{\mathrm{D}}\right)$

$\mathrm{V}_{\mathrm{E}}=\mathrm{V}_{\mathrm{F}}-\mathrm{V}_{\mathrm{D}}$

$\mathrm{V}_{\mathrm{D}}=\mathrm{W}_{\mathrm{D}} * \mathrm{~V}_{\mathrm{F}}$

where:

$\mathrm{V}_{\mathrm{F}}$ is firm value

$\mathrm{FCFF}_{\mathrm{t}}$ is the free cash flow to the firm in each year $t$, consistent with Damodaran (2002)

WACC is the weighted average cost of capital

$\mathrm{N}$ is the number of years in the forecast period

$\mathrm{G}$ is the constant growth rate in FCFF after the forecast period

$\mathrm{R}_{\mathrm{D}}$ is the after-tax cost of debt

$\mathrm{W}_{\mathrm{D}}$ is the weight on debt in the target capital structure, or the target debt ratio

$R_{E}$ is the cost of equity

$\mathrm{V}_{\mathrm{E}}$ is the value of equity, and

$\mathrm{V}_{\mathrm{D}}$ is the value of debt 
The "textbook" assumption that all claims on the firm can be classified as either debt or equity was adopted. While $R_{D}$ and $R_{E}$ can be thought of as functions of asset risk and leverage, since the textbook method assumes that the target debt ratio is known, $R_{D}$ and $R_{E}$ are also known. Substituting equation (2) into equation (1) for WACC yields an estimate of firm value. Next, subtracting the current value of debt from firm value in equation (3) yields an estimate of equity value. This estimate is of equity value is correct, but only under the assumption that we have the correct target debt ratio for the firm. What makes the estimate correct is that there is an implicit assumption that immediately after the transaction, the firm will, in the case that the firm was undervalued, borrow money to increase its debt ratio and pay out the proceeds to the shareholders, or in the case that the firm was overvalued, decrease its debt ratio by paying shareholder funds to debt holders. This assumption might be workable when the analyst will have control of the subject firm if a transaction takes place. It is common in leveraged buyouts, for instance, for acquirers to base valuation partly on how much leverage a target firm can carry. The assumption is also realistic in a capital budgeting project, which can be thought of as the purchase of a mini-firm. However, if the analyst is evaluating a passive investment in a publicly traded stock, it does not make sense unless one wants to allow for the typical passive equity investor to adjust his own leverage after making the investment.

\section{A NUMERICAL EXAMPLE OF THE TEXTBOOK METHOD}

Let:

$\mathrm{N}=5$

$\mathrm{FCFF}_{1}=48$

$\mathrm{FCFF}_{2}=72$

$\mathrm{FCFF}_{3}=82.56$

$\mathrm{FCFF}_{4}=-28.80$

$\mathrm{FCFF}_{5}=94.56$

$\mathrm{G}=3 \%$

$\mathrm{R}_{\mathrm{D}}=6 \%$

$\mathrm{V}_{\mathrm{D}}=300$ (current debt level)

$\mathrm{R}_{\mathrm{E}}=14 \%$

$\mathrm{V}_{\mathrm{E}}=200$ (current market value of equity)

$\mathrm{W}_{\mathrm{D}}=0.60(300 /(300+200))$

First, solve for WACC using (2):

$\mathrm{WACC}=0.06 * 0.60+0.14 * 0.40=0.092$

Next, solve for $\mathrm{V}_{\mathrm{F}}$ using (1):

$\mathrm{V}_{\mathrm{F}}=48 /(1+0.092)^{1}+72 /(1+0.092)^{2}+82.56 /(1+0.092)^{3}+-28.80 /(1+0.092)^{4}+94.56 /(1+0.092)^{5}$

$+97.379 /(0.092-.03) *(1 /(1+.092))^{5}=1220.052$

The next step in the textbook method for equity valuation is to solve for $\mathrm{V}_{\mathrm{E}}$ using (3):

$\mathrm{V}_{\mathrm{E}}=1220.052-300=920.052$

But having calculated firm value, it would have been equally valid to have solved for the value of debt using (4), and then solved for equity value using (3):

$\mathrm{V}_{\mathrm{D}}=0.60 * 1220.052=732.031$

$\mathrm{V}_{\mathrm{E}}=1220.052-732.031=488.021$

It turns out that 920.052 is the correct equity value, but only because the firm was undervalued, and with a $60 \%$ target debt ratio, equity holders can issue 432.031 (732.031-300) in new debt and simply put the money in their 
pockets. A leveraged buyout firm could potentially offer a very significant premium to purchase both the equity and debt of the subject firm and earn significant excess returns after relevering the assets at the target debt ratio. If the analyst is unwilling or unable to lever up, then the equity is not worth 920.052 .

\section{THE ITERATIVE METHOD}

The previous example highlights the sensitivity of equity value to the assumed target debt ratio. But does it even make sense for an analyst to begin the valuation process by specifying a target debt ratio? Since the expected magnitude and variability of future firm cash flows are a major determinant of desired leverage for most firms, it seems that an analyst who knows enough to estimate the subject firm's target debt ratio already knows enough to estimate firm and equity value. Further, alert students and practitioners are sometimes dissatisfied with the use of the current market value of equity to estimate the target debt ratio. The hypothesis that firms adjust leverage in response to fluctuating stock prices seems implausible to practitioners who don't take market efficiency as a given, but who in fact might be performing the valuation for the very purpose of trying to identify a deviation from semi-strong efficiency. It seems more plausible to many practitioners that managers set target debt ratios in relation to their estimates of intrinsic values, which are driven by estimates of future cash flows. Alert students and practitioners sometimes then point out that using the intrinsic value of equity results in circularity: the analyst needs to know the value of equity to know the target debt ratio and the WACC, and he needs to know the WACC to know firm and equity value.

There has been a number of prior studies that address the issue of circularity in the WACC. Much of this prior work is summarized in Velez-Pareja and Tham (2005). Circularity is generally dealt with by using an iterative procedure to solve for $\mathrm{V}_{\mathrm{E}}$. If we substitute equation (4) into (2) for $\mathrm{W}_{\mathrm{D}}$, equation (2) into (1) for WACC, and equation (3) into (1) for $\mathrm{V}_{\mathrm{F}}$, we get the following equation (5):

$\mathrm{V}_{\mathrm{E}}=\mathrm{FCFF}_{1} /\left(1+\left(\mathrm{R}_{\mathrm{E}} *\left(1-\left(\mathrm{V}_{\mathrm{D}} /\left(\mathrm{V}_{\mathrm{D}}+\mathrm{V}_{\mathrm{E}}\right)\right)\right)+\mathrm{R}_{\mathrm{D}} *\left(\mathrm{~V}_{\mathrm{D}} /\left(\mathrm{V}_{\mathrm{D}}+\mathrm{V}_{\mathrm{E}}\right)\right)\right)\right)^{1}+$
$\ldots+\mathrm{FCFF}_{\mathrm{N}} /\left(1+\left(\mathrm{R}_{\mathrm{E}} *\left(1-\left(\mathrm{V}_{\mathrm{D}} /\left(\mathrm{V}_{\mathrm{D}}+\mathrm{V}_{\mathrm{E}}\right)\right)\right)+\mathrm{R}_{\mathrm{D}} *\left(\mathrm{~V}_{\mathrm{D}} /\left(\mathrm{V}_{\mathrm{D}}+\mathrm{V}_{\mathrm{E}}\right)\right)\right)\right)^{\mathrm{N}}$
$+\mathrm{FCFF}_{\mathrm{N}+1} /\left(\left(\mathrm{R}_{\mathrm{E}} *\left(1-\left(\mathrm{V}_{\mathrm{D}} /\left(\mathrm{V}_{\mathrm{D}}+\mathrm{V}_{\mathrm{E}}\right)\right)\right)+\mathrm{R}_{\mathrm{D}} *\left(\mathrm{~V}_{\mathrm{D}} /\left(\mathrm{V}_{\mathrm{D}}+\mathrm{V}_{\mathrm{E}}\right)\right)\right)-\mathrm{G}\right)$
$* 1 /\left(1+\left(\mathrm{R}_{\mathrm{E}} *\left(1-\left(\mathrm{V}_{\mathrm{D}} /\left(\mathrm{V}_{\mathrm{D}}+\mathrm{V}_{\mathrm{E}}\right)\right)\right)+\mathrm{R}_{\mathrm{D}} *\left(\mathrm{~V}_{\mathrm{D}} /\left(\mathrm{V}_{\mathrm{D}}+\mathrm{V}_{\mathrm{E}}\right)\right)\right)\right)^{\mathrm{N}}-\mathrm{V}_{\mathrm{D}}$

We assume that the value of the debt will not change as a result of the transaction, leaving equity value as the only unknown in equation (5). Pitabas (2006) presents a simple iterative spreadsheet procedure that can be used to solve equation (5) for $\mathrm{V}_{\mathrm{E}}$. To apply the iterative method, we first value the firm using the textbook method, calculating the weights using the current market value of equity as $\mathrm{V}_{\mathrm{E}}$. Next, we check whether the estimated value of equity using the textbook method is equal to the $\mathrm{V}_{\mathrm{E}}$ that was used to compute the weights on debt and equity. If so, the equity was priced correctly and the process is finished. If not, repeat the valuation using the estimated value of equity from the first attempt as $V_{E}$ to compute the weights in the second attempt. If the estimated value of equity in the second attempt equals the $\mathrm{V}_{\mathrm{E}}$ used to compute the weights in the second attempt, the process is finished. If not, keep repeating the valuation until the estimated values of equity converge. It is extremely simple to execute the iterative method in an Excel spreadsheet. No special functions or add-ins are needed. Table 1 presents the results of applying the iterative method to the example presented earlier.

In this example it takes fifteen attempts for the equity values to converge to the correct value of 585.871. Sometimes it might take more than fifteen attempts for the equity values to converge, so spreadsheets should be built with plenty of rows. Table 1 is the only addition that is needed to a textbook valuation spreadsheet in order to obtain the correct WACC, $\mathrm{V}_{\mathrm{F}}$, and $\mathrm{V}_{\mathrm{E}}$ with the iterative method. The formulas in the WACC column are simply equation (2) with $V_{E}$ changing on each row to match the estimated value of $V_{E}$ from the previous row. Equity value enters equation (2) through the debt ratio: . $\mathrm{W}_{\mathrm{D}}=\mathrm{V}_{\mathrm{D}} /\left(\mathrm{V}_{\mathrm{D}}+\mathrm{V}_{\mathrm{E}}\right)$. The key to the procedure is that the beginning estimate of $\mathrm{V}_{\mathrm{E}}$ used in computing the weights is updated with each attempt. The formula in cell C3, for example, is simply =E2. The FCFF equity value in the last column is simply the computed FCFF firm value minus 300, the value of debt. Of course the appropriate values of $\mathrm{R}_{\mathrm{D}}, \mathrm{T}, \mathrm{V}_{\mathrm{D}}, \mathrm{R}_{\mathrm{E}}, \mathrm{G}$, and each year's FCFF must also be entered into the other cells of the spreadsheet not shown here. 
Table 1: The Iterative Method for Estimating $V_{F}$ and $V_{E}$

\begin{tabular}{|c|c|c|c|c|c|}
\hline & A & B & C & D & E \\
\hline $\mathbf{1}$ & Attempt Number & WACC & Beginning VE & FCFF Firm Value & FCFF Equity Value \\
\hline 2 & 1 & 0.092 & 200.000 & 1220.052 & 920.052 \\
\hline 3 & 2 & 0.120 & 920.052 & 805.148 & 505.148 \\
\hline 4 & 3 & 0.110 & 505.148 & 919.251 & 619.251 \\
\hline 5 & 4 & 0.114 & 619.251 & 874.327 & 574.327 \\
\hline 6 & 5 & 0.113 & 574.327 & 890.138 & 590.138 \\
\hline 7 & 6 & 0.113 & 590.138 & 884.331 & 584.331 \\
\hline 8 & 7 & 0.113 & 584.331 & 886.432 & 586.432 \\
\hline 9 & 8 & 0.113 & 586.432 & 885.668 & 585.668 \\
\hline 10 & 9 & 0.113 & 585.668 & 885.945 & 585.945 \\
\hline 11 & 10 & 0.113 & 585.945 & 885.844 & 585.844 \\
\hline 12 & 11 & 0.113 & 585.844 & 885.881 & 585.881 \\
\hline 13 & 12 & 0.113 & 585.881 & 885.868 & 585.868 \\
\hline 14 & 13 & 0.113 & 585.868 & 885.872 & 58.872 \\
\hline 15 & 14 & 0.113 & 585.872 & 885.871 & 585.871 \\
\hline 16 & 15 & 0.113 & 585.871 & 885.871 & 585.871 \\
\hline
\end{tabular}

Using the iterative method, we estimate that the intrinsic value of equity is 585.87. Since the current market value of the firm's equity is 200 , we estimate that the market is undervaluing the equity by 385.87 . The estimated $\mathrm{V}_{\mathrm{E}}$ of 585.87 implies a debt ratio of $300 /(300+585.87)=0.339$ and a WACC of .113 . The degree of estimated under valuation in the iterative method is less than in the textbook method. The reason for this is that we use the same cost of equity and cost of debt that we use in the textbook method, but the weight on debt is significantly lower in the iterative method. As the cost of equity is higher than the cost of debt for a given debt ratio, the higher weight on equity and lower weight on debt in the iterative method results in a higher WACC and a lower values of $V_{E}$ and $V_{F}$. In many cases the cost of equity $R_{E}$ is specified as an increasing function of the debt ratio and the cost of equity $R_{U}$ that would apply at a debt ratio of 0 . The iterative method can easily be adapted to this specification for $R_{E}$ by adding a column for the calculation of $R_{E}$ to Table 1 . Finally, it is important to emphasize that it is only the current value of debt that is taken as a given in the iterative method. The value of debt can, and likely will, change through time as firm value evolves.

\section{CONCLUDING REMARKS}

The textbook method of equity valuation using the WACC is appropriate only when the analyst is confident in his estimate of the target debt ratio and in the prospect that the firm will adjust toward the target in the immediate future. In the example presented above, with equity undervalued, it is not enough to know that the subject firm has plenty of excess debt capacity; the analyst must also be confident that management will take advantage of the excess debt capacity to recapitalize the firm. This assumption is appropriate when the analyst has control or is contemplating acquiring control of the subject firm or project. It works well for capital budgeting projects and acquisitions in which debt capacity can be estimated with some confidence, and poorly for passive equity investments and investments for which unused debt capacity is difficult to estimate. To value passive equity investments, the analyst should use the iterative method with the WACC or another discounted cash flow technique, such as discounting free cash flows to equity at the cost of equity. The best choice of DCF model depends on the exact assumptions that the analyst wishes to make. While finance textbook authors and finance scholars undoubtedly understand the implications of using the WACC in equity valuation, the lack of emphasis on this important topic in financial education has resulted in unnecessary confusion among students and practitioners. This confusion has the potential to lead many practitioners and future practitioners to turn their backs on DCF models altogether in favor of multiples based valuation and other less confusing but potentially less accurate techniques. 


\section{AUTHOR INFORMATION}

Patrick J. Larkin was born in Lake County, Florida, in 1967. He received his B.A. in economics from the University of Florida in 1989. After graduation, Patrick worked in the real estate and television production industries. Patrick received his M.A. in economics from Syracuse University in 1996 and his Ph.D. in financial economics in August of 2001 from the University of New Orleans. Patrick is currently a professor of finance at Fayetteville State University. Patrick has published articles in the Journal of Banking and Finance, the Journal of Financial Education, and numerous other referred academic journals. E-mail: plarkin@uncfsu.edu

\section{REFERENCES}

1. Brealey, Richard A., Stewart C. Myers, and Franklin Allen, Principles of Corporate Finance, 2011, McGraw-Hill Irwin, New York, ISBN: 978-0-07-353073-4.

2. Damodaran, Aswath, Investment Valuation, Tools and Techniques for Determining the Value of Any Asset, 2002, John Wiley \& Sons, Inc., New York, ISBN 0-471-41488-3.

3. Mohanty, Pitabas, A Practical Approach to Solving the Circularity Problem in Estimating the Cost of Capital (January, 2006). Available at SSRN: http://ssrn.com/abstract=413240 or doi:10.2139/ssrn.413240.

4. Velez-Pareja, Ignacio, and Tham Joseph. 2005. "Proper solution of circularity in the interactions of corporate financing and investment decisions: A reply to the financing present value approach." Management Research News 28, no. 10: 65-92. 


\section{NOTES}

